\title{
Financing Afforestation in the Organization of Islamic Cooperation Countries: What Role for Islamic Economics and Finance?
}

\author{
Shafiu Ibrahim Abdullahi \\ Sule Lamido University, Kafin-Hausa, Jigawa, Nigeria
}

\begin{abstract}
This paper looks at environmental conservation within the growing understanding of the urgent need to confront the two menaces of desertification and deforestation through afforestation schemes in the Organization of Islamic Cooperation (OIC) member countries. Deforestation is one of the main contributors to global greenhouse gas emissions, ecosystem degradation, and from there the rising cases of poverty in the developing world. Their impacts on the economy and environment of OIC member countries has been devastating. Desertification and deforestation are caused by human activities like logging, harmful farming practices, as well as haphazard cutting of trees in order to make way for city buildings and farms. The paper shows that poor handling of past responses to desertification problems can be solved with the right approaches. It first looks at existing approaches to the problem and causes of their failure. Then, it proposes an alternative model based on fiqh teachings and recent developments in Islamic economics and finance. The paper syntheses conventional and Islamic approaches towards solving the problems of desertification, deforestation, and rising temperatures in the OIC countries. It delineates specific functions and contributions of each one of (a) the Islamic state, (b) the institution of waqf, (c) Islamic finance, and (d) the Islamic firm.
\end{abstract}

Keywords: Afforestation, Desertification, Deforestation, Market failure.

JEL Classification: H2, H4, H5, H8, K32

KAUJIE Classification: B1, E2, E3, H2, H3 


\section{Introduction}

The deliberate neglect of environmental issues by conventional economic literature has not changed much over the past decade or so (Dasgupta \& Maler, 1991, pp.101-103; Dasgupta, Hamilton, Pagiola, \& Wheeler, 2008, pp. 4-7). The election of Donald Trump as president of the United States has further put into question western countries' commitments to environmental causes and the promises they made over the years. Since the start of the industrial revolution, the damage done to the world natural habitat as a result of man's destructive activities cannot be quantified. The rates at which natural disasters and environmental harms such as flooding, hurricanes, desertification, global warming, rise in sea level, erosion, etc., are occurring have increased over the years. However, the multinational and local responses to them have been poor or not forthcoming. Even among firms, the application of corporate social responsibility (and other voluntary activities that reduce profits) has remained marginal (Hepburn, 2010, p. 126). Modern firms are the worst polluters in the world. Their contribution to pollution is more than that of any other sector, but so far, they are the most reluctant to contribute to finding solutions to the menace. Even the biggest development institutions in the world only came to care about the environment after the damages have reached severe levels. For example, the World Bank only established an environment department in 1988, long after the devastation of environment by policies of the bank and industrialized countries (Shihata, 1992, p. 7).

Over the years, there was neglect in searching for religious solutions to the problems of environmental degradation. Instead, the focus has remained on questionable methods which have failed to get the desired results. Islam, like with other human ills, has a lot to say on how to deal with environmental problems. In the Holy Qur'ān (6:141, 7:31, 26:151-152), Allah has warned against wastage caused by over-consumption and exploitation. In another verse, Allah says: "So eat and drink of the sustenance provided by Allah, and do no evil nor mischief on the (face of the) earth" (2:60). Allah warns against the destruction of plants and animals in the Holy Qur'ān (2:205) and admonishes the mischief makers (5:64).
Islamic life rests on three major fundamentals: tawhīd, khiläfah, and al-ãkhirah (Akhtar, 1996, p. 63). Tawhìd, according to Choudhury (2010, p. 209), refers to the strict monotheism of Allah. The tawhid principle creates the moral and religious motivation for environmental protection and security. Allah has created human beings as His khalifah in order to submit to His will in all aspects of life. The concept of al-äkhirah means that man evaluates the likely impact of his worldly choices on his life in the hereafter before taking any decision (Akhtar, 1996, p. 64). Even during periods of war, Muslims are not allowed to harm plants. The Prophet (may the peace and blessings of Allah be upon him) is reported to have said: "There is no Muslim who plants a tree or sows a field, and a human, bird, or animal eats from it, but it shall be reckoned as charity from him" (alNaisabouri, 1991, 3:1189, hadìth no. 1553; Akhtar, 1996, p. 65). Perhaps the main distinguishing feature of modern treatment of Islamic economics is the emphasis it places on moral, social, and sustainability directives found within the Islamic body of knowledge. The Holy Qur'ān presents a grand ecological model of general wellbeing for mankind and the total environment (Choudhury, 2010, p. 213).

Growing environmental challenges have led to today's obsession with concepts such as 'smart city' where it is thought that cities of the future will be made to conform to the demands of sustainability. At the heart of the concept is the greening of cities, covered in gardens of trees and environmental harmony. Thus, afforestation is the future of smart cities and their surrounding areas. Climate change, and the arid future prospect of the world that it depicts, made modern city designers to think again about the need to design cities that are friendly to the environment. For example, in line with this, China is building a forest city in Liuzhou; an entire city where plants will blanket its every building and boulevard. The developers of the city claim 'Liuzhou' can absorb over 10,000 tons of $\mathrm{CO}_{2}$ and other pollutants a year while producing nine hundred tons of oxygen. It is hoped that as the world gets increasingly urbanized, this approach could help make the world more livable (Emewu, 2017). 
Local commons such as forests in village areas as well as large gardens in cities are some of the few sources of relief to the poor man who cannot afford to build his own private garden or go on vacation elsewhere where there are forests. They also provide an important source of livelihood for him. For example, the agroforestry system in Indonesia is very vital to the economy of its people. It includes fruit trees such as durian, jengkol, petai, and other indigenous trees (Djanibekov \& Villamor, 2015, p. 4). The same is true in other countries who support agroforestry and other similar projects. However, farming systems themselves contribute to water scarcity and dryness of the environment around the world. A report published in The Economist ("Briefing: Water scarcity...", 2016) observed that the modern extravagant lifestyle has contributed to water scarcity as a result of wastage of agricultural output, which itself consumes a lot of water during production. It, therefore, calls for a moderation in lifestyles and changes in farming methods by adopting farming technology like drip irrigation.

This paper discusses models for solving the problems of desertification and rising temperatures in OIC member countries. Its objectives are three fold (1) to demonstrate the damage desertification is doing to the environment, (2) show the failures of conventional methodologies of dealing with the menace, and (3) propose new ideas for dealing with the problem.

\section{Literature Review}

\subsection{Environment and Desert Encroachment}

The problems of desertification and their impacts are very real. In Nigeria, Kano city (northern Nigeria) is only about $250 \mathrm{~km}$ from the Sahara Desert that lays further north of it. Kano, like most cities around it, is open to the possibility of being eaten by the Sahara Desert. Kano state alone is home to some 12 million people while the whole region is home to more than 80 million people. The responses of authorities in the region to the problem was dismal. In the PersianGulf, it was found that the frequency of warm days has significantly increased in the period 1961-2005 (Yazdanpanah, Eitzinger, \& Baldi, 2017, p. 427).

One noble and time-tested way of tackling the desertification problem is afforestation. For some time now, the rich world is spearheading a worldwide campaign for the creation of a market for forestry and its products. Forestry ignored co-benefits include carbon storage and watershed management ("Special report...", 2002). It also goes with the call on rich countries to pay poor countries to protect their tropical forests. However, so far, the rich countries have failed to adhere to this commitment (Hepburn, 2010, pp. 130-131). The developed countries of the world have refused to follow this line because of selfish interests. What is being witnessed today is proliferation of theories that falsify the existing academic works that proved global warming and other environmental degradation. The attitude of the developed countries does not help matters in this regard. Their drive for industrialization in the last 150 years has been responsible for the current global warming and other environmental epidemics. Colonialism in itself has contributed in pushing deforestation activities to environmentally harmful levels in countries like Malaysia, Nigeria, Indonesia, Ivory Coast, and Guinea. A study by the Third World Institute (Third World Institute, 1999, p. 4) pointed out Malaysia as a nation where logging has contributed to deforestation activities.

Deforestation has made life difficult for the poor and threatens their source of livelihood in farming and animal rearing. The use of wood for domestic fuel has been one of the major causes of deforestation and land degradation. Likewise, migration patterns where rural peasants are forced to migrate out of their villages into new areas, has forced them into clearing new forests to make way for farms and houses (Courcelle, Sevaistre, \& Stinzty, 2004, p. 40). In poor countries, poverty causes environmental degradation due to the increase in population pressure and the need to clear more forest for farming (Kadandani, 2005, pp. 31-34).

The results of deforestation and desertification include drought and famine that frequent countries ravaged by environmental problems. In most poor countries, environmentally harmful farming accounted for most of the deforestation activities; thus, creating a vicious cycle between farming practices and desertification. Hence, good farming methods that help increase soil fertility should be encouraged. Sustainable farming also has the effect of reducing the cost of maintaining soil and the need to clear more forest areas for farming activities. 
Most of the Middle Eastern countries' environment is occupied by deserts which makes their environment very hash and difficult to live in. Similar is the case in other parts of the world with substantial population of Muslims such as Central Asia and Sub Saharan Africa. Analysis has shown that increase in the level of heat around the world is responsible for a number of deaths especially among children and elderly (Yazdanpanah et al., 2017, p. 419). Studies such as that of Roger $(1984$, p. 213) found out that only $14 \%$ of inhabited land and about $25 \%$ of cultivated land falls under the territorial control of the 15 largest economies in South and East Asia, despite having about half of the total world population. According to World Bank estimates, forest fires cost Indonesia about $\$ 16$ billion in losses in forestry, agriculture, tourism, and other related activities while also causing the deaths of around 100,000 people ("For peat's sake...", 2016).

Various measures have been taken over the years towards stopping desert encroachment, including tree planting campaigns, enacting of laws against cutting of trees, payments for environmental services (PES) to the providers of these services through compliance (e.g., Clean Development Mechanism [CDM]), and the creation of voluntary markets. Studies on economic sustainability talk of important links between the standard of living of people and farmers in rural areas and the preservation or deterioration of environment, mainly soil degradation (Courcelle et al., 2004, pp. 40-41). In order to survive, poor farmers adopt all kinds of harmful farming methods irrespective of their impacts on the environment.

Theories such as Romm hypothesis, show that the proportion of land in forest cover has a U-shaped relationship with the population density and a direct relationship with the income level (Sargent \& Bass, 1992, p. 213). This may help, to some extent, in explaining the vicious cycle between poverty and desertification in Africa and other regions of the world. The hypothesis explains how the proportion of land under forest cover increases as the level of income increases. Thus, it means (to some extent) that a highly forested nation is a rich nation. However, this may also be as a result of poor countries' specialization in primary products. The argument put forward in the early 1990s that economic growth is necessary for environment quality to increase has been led to rest
(Stern, 2003, p. 2; Stern, 2004, pp. 1419-1421; Dinda, 2004, pp. 447-450). Hence, the rise and fall of the well-known Environmental Kuznets Curve (EKC) popularized together with that hypothesis. While Romm hypothesis specifically addressed forest cover, $\mathrm{EKC}$ is concerned with general environmental quality, thus involving a lot of variables.

\subsection{Economics of Afforestation}

Afforestation generally is linked with restoring vegetation, control of erosion and climate change, providing foods and sources of living, as well as provision of raw materials (Ibrahim \& Muhammad, 2015, p. $25)$. Forests are beneficial not only because they supply raw materials (which is a flow service), but because they prevent soil erosion (which is a stock), and control climate (Dasgupta \& Maler, 1991, pp. 109110). Agroforestry is one of the land use options available to enhance the provision of various ecosystem services (ES), e.g., carbon (C) sequestration (Djanibekov \& Villamor, 2015, p. 2). According to empirical studies, planting trees on marginal croplands increases the opportunity for cropping the most profitable crops such as rice and vegetables, due to the supply of irrigation water unused at afforested plots to these water demanding crops (Djanibekov, Khamzina, Villamor, \& Lamers, 2013, pp. 12-15). The same study also found the use of land previously used for conventional farming for afforestation farming to be more profitable. History of man afforestation activities is as long as human civilization itself. Man has, since time immemorial, known the benefits of planting trees to himself and the environment. However, despite the known benefits of afforestation, deforestation and desertification have been allowed to destroy the beneficial impacts of afforestation. It is in recognition of this that serious governments around the world are making concerted efforts to combat the twin evils of desertification and deforestation for proper habitation and sustainable development.

Generally, valuation of environmental resources has remained open to controversies. One such controversy relates to the right way of pricing them (using shadow pricing or actual market clearing prices). Thus, the question that should be asked here is, what is the right price for forest resources? This question is very important in looking at the appropriate way to 
finance the establishment of forestry plantation and putting a stop to harmful logging activities. Pricing of natural resources is a bit tricky, unlike ordinary commodities sold in the market. The popular Pareto optimality has been widely used as a mechanism for making various kinds of economic decisions including price determination, however, the practical application of it has remained minimal. A good pricing criterion for forest resources should take into account their scarcity, the cost of replacing them, and their value to the environment as well as to the future generations. Thus, imposing control on logging activities by means of direct control, tax, or trade and cap method will definitely increase the cost of wood's use for different types of functions. However, creating a market in agroforestry is the right way to go in order to boost afforestation activities in OIC countries. It will also help stop illegal logging activities and other harmful practices.

Using market-based instruments (MBI) could be an option in increasing the financial benefits of environmentally friendly afforestation activities. According to studies, MBI rewards can be obtained from the Carbon stored in the wood biomass of agroforestry systems as well as revenues obtained from mechanisms like reducing emissions from deforestation activities and forest degradation (Djanibekov \& Villamor, 2015, p. 2). In the last few years, there were different efforts in Nigeria to encourage farmers to go into Gum Arabic plantation as a viable farming business. This, apart from the income and employment it generated, also protected the environment and helped regulate the climate. Afforestation of marginal land has become a business venture in a number of countries (Djanibekov, 2014, p. 10). Afforesting marginal croplands in Uzbekistan has been found to increase the productive potential of land and has contributed to climate change mitigation, efficiency of irrigation water use, and rural incomes (Djanibekov et al., 2013, pp.14-15). Traditional sharecropping in Indonesia has played an important role in the development of plantation business. It links farmers who are interconnected to each other through the sharecropping arrangement, where one farmer (i.e., landlord) has more land to manage himself and another farmer (i.e., tenant) has insufficient land but abundance of labor (Djanibekov \& Villamor, 2015, pp. 11-13). Economic trees have the advantage of increasing soil nutrients, protecting soil from erosion, providing feed supplement to both farmers and their livestock, serving as firewood (Ahmed, 1997, p. 129).

\subsection{Market Failure}

The term market failure is generally used to describe the failure of the market economy to achieve an efficient allocation of resources (Lipsey \& Chrystal, 2004 , p. 320). Thus, market failure provides governments with excuses to intervene with the hope of improving efficiency. Governments have been blamed for many things, among which are bureaucracy and corruption, which the advocates of privatization see as one of the reasons for restricting governments from running the economy. Governments are seen as too rigid and usually take more time to work on a simple decision. Government failure, according to Lipsey and Chrystal (2004, p. 357), arises from the government's own objectives. Governments continuing to subsidize things like agriculture is still a matter of market failure where the market on its own fails to provide things that governments consider essential. Public choice theory, for example, looks at who are the gainers and losers from a particular policy, and based on that, the next decision is taken. According to Hillman (2003, p. 3), a society should be happy with the market system if it achieves two basic objectives: efficiency, and social justice. Both the free market and government control systems have failed (to some extent) when it comes to the issue of environment (Hepburn, 2010, pp. 123-127). Governments have many responsibilities in the economy. Among them is what is termed as minimal governance which is simply the overseeing of competitive markets and ensuring the rule of law (Hillman, 2003, p. 113). However, minimal government does not ensure social justice, environmental protection, and sometimes even efficiency. Under the existing framework, models of environmental economics range from total government intervention through planning, to private individual participation as a business endeavor (Hepburn, 2010, pp. 121-125).

Externality itself arises due to lack of property rights (Lipsey \& Chrystal, 2004, p. 328). If there are clear property rights, no case of externality will arise. As an example of market failure and improper application of property rights, a timber merchant who obtains a permission to cut trees is under no obligation 
to compensate the farmers whose farms he causes to be flooded due to deforestation. However, on the other hand, it is the farmers who must compensate him if they want him to reduce deforestation (Dasgupta \& Maler, 1991, p. 112). Ideally, it is the timber merchant that is supposed to pay the farmers for polluting their farms. In the real sense, how many loggers pay the full cost of cutting trees? Thus, the social cost of logging is higher than the private cost. This is why governments must intervene in situations where the market fails to correct for externalities and restore balance. The existing models being used to ensure sustainability such as carbon tax, emission control, and trading in permits have done little to stop the destruction of the environment happening elsewhere around the world. That is not to say that it is possible to live in a world with zero externalities that damage the environment such as forest destruction, but at least humans should make efforts to minimize the externalities to a level allowed by economic fundamentals. Government regulation is necessary in controlling environmental damages. However, direct government control in some circumstances has been found to be ineffective and economically inefficient. An alternative method to direct government control is such a tax which internalizes the externalities; though, the existing tax schemes have their own weaknesses. These are discussed under Pigouvian tax.

Market and government failure can also be found in the way and manner afforestation programs are financed. The traditional method of financing afforestation in most developing countries, the system of annual budgeting, has its own problems. There is the untimely release of funds that sometimes comes after the appropriate time of planting seeds has passed. There is also the problem of corruption where financial embezzlement on the part of those entrusted with public money makes it difficult for money to reach those that need it the most. In the Sahelian Africa, the combined effects of corruption, crop failure, high rate of bank interest, lack of access to credit, and the continued use of traditional share cropping way of financing have made tree planting difficult. Some of the existing institutions such as banks of agriculture, established with the aim of financing farming and related activities, have failed to deliver for the same reasons mentioned above. Private banking institutions shun rural farmers who they see as unbankable, and due to the externalities, the problem is declared as a market failure. Government failure is also to blame as governments fail to address the causes of the problem. Instead, governments create an atmosphere for maintaining the status quo without hindrances. This has turned a small problem that can be handled at source into a systemic problem. Thus, some presumed public goods can be handled by the market. However, due to politics and corruption, the markets themselves are not allowed to work properly.

\section{An Approach Towards Rolling Back Desertification in OIC Member States}

As discussed in the above section, the problems of deforestation and desertification require more attention than policy makers give it. Unlike other areas of economics, such as finance, consumer theory, international trade, or taxation, the literature on sustainable economic development is at the infancy level. This has happened because economists have started to give the problem the attention it deserves only lately. This section proffers solutions to the problems of desertification and deforestation. The approaches towards the problem are categorized as: public sector (government), voluntary sector, and private sector approaches. 


\section{Figure (1) Sources of Solutions to Afforestation}

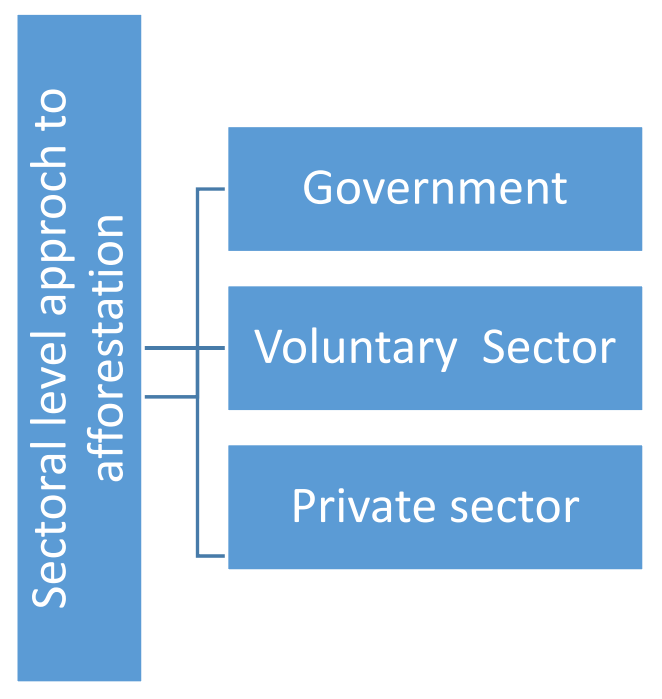

Source: Author's analysis.

(1) Public sector: role of government using the proceeds of taxation and statutory allocations to solve afforestation challenges, government sponsored development finance institutions like the Islamic Development Bank (IDB), and other national level and multinational finance corporations.

(2) Voluntary sector: institution of waqf through private donation of wealthy individuals.

(3) Private sector: Islamic firms such as Islamic banks, takāful institutions, capital market firms, and other Sharī ah-compliant organizations.

\subsection{Responsibilities of the State in Addressing the Problem of Desertification and Deforestation}

Islam stands for free markets. It requires governments to merely oversee if the tenets of the Shari' ah are being observed in letter and spirit (Hasan, 2008, p. 8). According to Bashar (1997, pp. 47-49), an Islamic state can control the price where it becomes necessary such as during an emergency or to stop monopoly as demanded by the Sharíah in compliance with the principle of mașlahah. It, therefore, means that Islam is not opposed to market determination of prices in as much as it does not clash with the Islamic Sharī'ah. Islam, according to Hasan (2008, p. 10 ), wants to see markets operate for promoting social good in conformity with Sharī'ah norms. Thus, without any doubt, the role of both state intervention and the market mechanism cannot be ruled out in finding solutions to the problems of desertification and deforestation. Governments in an Islamic economy co-exist in the market with the private sector on a permanent and stable basis (Hasan, 2008, pp. 8-10).

In an Islamic economy, public choice is guided by the mașlahah principles. The maqāssid al-Sharì ah (objectives of the Shari'ah) focus on promoting and safeguarding human welfare in this life as well as in the Hereafter (Oran, 2010, p. 127). These maqāssid are "to promote the well-being of all mankind which lies in safeguarding their faith $(d \bar{i} n)$, their human self (nafs), their intellect ('aql), their posterity (nasl) and their wealth ( $m \bar{a} l)$ )" (Hasan, 2006, p. 8). Al-Raysuni (1992), defined maqāșid al-Sharī'ah as, "The goals set by the Shari'ah to achieve the interests of the servants (people)" (p. 7). Hasan (2006, p. 8) also agrees that some of the conventional proposals towards solving the problem of environment are in consonance with the maqāssid al-Sharī'ah. However, in matters of pollution and practices harmful to the environment, there is more demand for government intervention than will be required in other sectors of the economy. The well-known concept of intertemporal resource allocation advocates reducing current resource consumption to provide for the next generation's consumption. This means minimizing logging, harmful farming practices, emission of toxic 
gases, etc., in order to leave a habitable world for the future generation. In this regard, Islamic countries can learn a lot from each other in the areas of agroforestry and tree planting campaigns, as some of them have achieved some level of success in this particular area. Malaysia and Indonesia (for example) are making efforts to replace trees lost through deforestation.

Governments should impose taxes specifically for the sector; what is generally called Pigouvian tax, on the mining and logging industries to pay for spending on afforestation activities. A Pigouvian tax, simply put, is a tax levied on any market activity that generates negative externalities such as pollution and environmental harms. The tax is only imposed to punish polluters who are by this act forced to pay for their environmentally harmful activities. Governments can also use cap and trade schemes to reduce logging activities in heavily forested countries like Malaysia, Indonesia, and Nigeria. Figure-2 shows how a Pigouvian tax works.

\section{Figure (2) Pigouvian Tax}

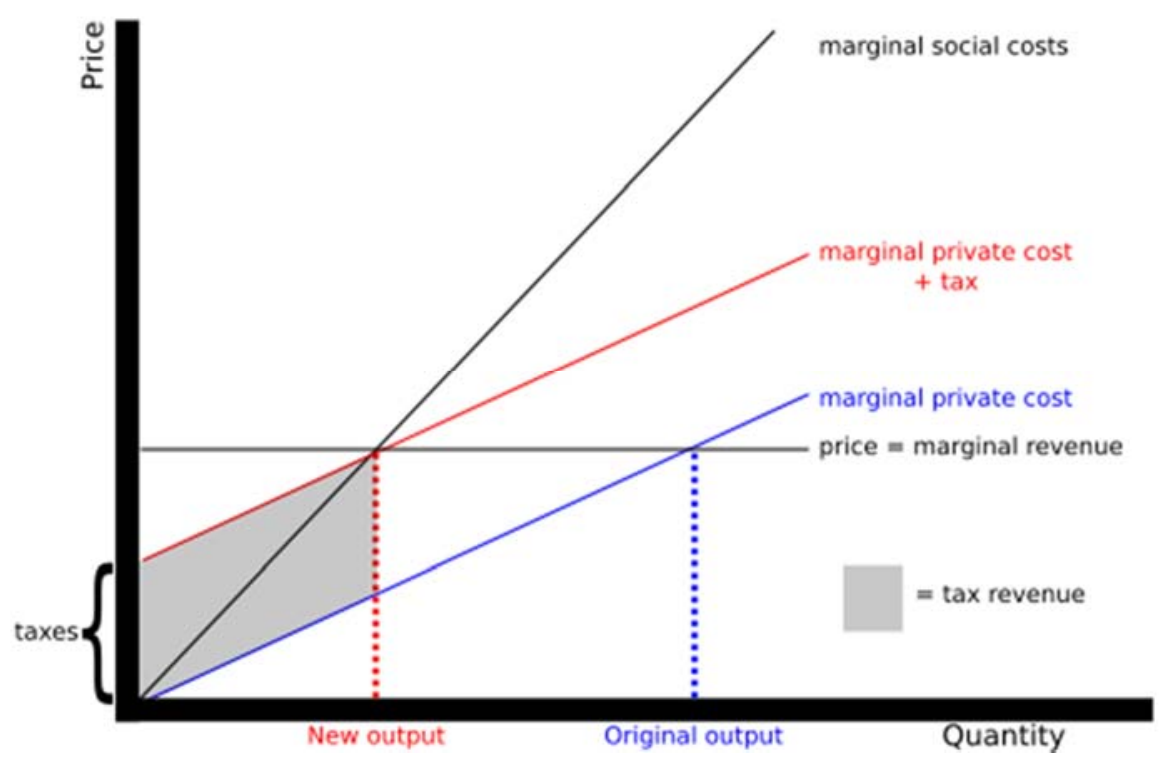

Source: Wikipedia (https://en.wikipedia.org/wiki/Pigovian_tax).

While cutting of trees has negative externalities, the planting of them has positive externalities. In view of this, some economists advocate the use of subsidies to help the growth and development of the sector. Due to this positive externality, forestry resources can be categorized as public goods. Though, some type of forestry resources can also serve as private goods. These include things like agroforestry products that are sold in the open markets. Economists argue that it is difficult to calculate the costs and benefits of most government activities; those that oppose a particular government project tend to hike its costs, while those that support it cut the overall cost in order to make the project attractive. However, under an Islamic system, the major yard stick is, of course, mașlahah; whatever conforms to mașlahah is desirable and whatever does not conform to it is not desirable. Thus, a tax imposed by the government which helps in increasing the total welfare is not bad in itself.

The fact that most Muslim countries are endowed with abundant hydrocarbon and other mineral resources whose exploitation contributes to the deterioration of the environment shall make it desirable for these countries to set up special funds for the environment, such as an afforestation fund to tackle 
desertification, deforestation and global warming. Islamic countries, according to Arafa (2014), "represent a hazardous source of environmental pollution to the world" (p. 467). In this regard, the Islamic Development Bank (IDB) and the OIC should establish an afforestation fund to cater for afforestation activities in member countries. In particular, poor IDB member countries that are suffering due to desertification and deforestation such as Niger, Mali, Mauritania, Palestine, Afghanistan, Somalia, Uzbekistan, Tajikistan, and others shall benefit from the fund. Rich IDB and OIC member countries such as Saudi Arabia, Qatar, Malaysia, Kuwait, Indonesia, UAE, Algeria, and Kazakhstan who engage in hydrocarbon exploitation shall contribute the major share of the fund resources. Likewise, countries who engage in excessive logging such as Malaysia, Nigeria, Indonesia, Turkey, and Guinea shall be persuaded to also contribute to the fund. A recent report on toxic countries that have made the least progress towards clean energy, puts some OIC countries as the most toxic in the world. Out of the ten most toxic countries, only one is not an OIC member. The report was put together by 'The Eco Experts' who gathered data on 135 countries and then ranked them based on five environmental factors: energy consumption per capita, $\mathrm{CO}_{2}$ emissions from fuel combustion, air pollution levels, deaths attributable to air pollution, and renewable energy production (Clark, 2017).

\subsection{The Institution of Waqf}

Recent treatments of environmental issues suggest striking a balance between the free market and government intervention as the way out (Hepburn, 2010, pp. 125-130). How to strike the right balance is still a matter of controversy. However, this is also the main weakness of mainstream economics in not considering the possible contribution of the socio-religious cause to the problems, which remains the major difference between Islamic economics and conventional economics. Instead, conventional economics has continued to push in the same direction using the same methodologies that brought the world to where it is today. Unlike conventional economics that neglects socio-religious considerations, these are the core foundations of Islamic economics. This is where the Islamic waqf system, which has been in existence since the early period of Islam, comes in. There is voluminous literature on the history and development of this great Islamic institution. According to Hassan and Ashraf (2010), awq $\bar{a} f$ "is a perpetual charity that means holding certain property and preserving it for the confined benefit of certain philanthropic purposes" (p. 267). Another definition puts waqf as "an unincorporated trust established under Islamic law by a living man or woman for the provision of a designated social service in perpetuity" (Kuran, 2001, p. 842).

Thus, Islamic economics offers an alternative to the government's financing of afforestation and the lack of private sector's participation in some areas of the sector due to market failure. What it is offering is a socio-religious alternative that has been tested and trusted for thousands of years; the waqf foundation of afforestation. Here, waqf is made to serve the real sector of an Islamic economy. Islamic history has instances where waqf was used as a driver of tree planting. Though, some researchers have argued that environmental protection formed a small part of the usage of waqf funds in the past (al-Anzi \& al-Duaij, 2004, pp. 62-63).

Generally, Islamic laws encourage afforestation, security of habitat, and discourage deforestation. Akhtar, (1996, pp.71-72), mentions that the Prophet (may the peace and blessings of Allah be upon him) forbade the cutting of trees in the desert. Therefore, he established a rule that the forest and the wild-life are free goods to be maintained under the trusteeship of the community. In Islam, the act of planting a tree is a charity that endows even when the doer has died as long as the tree is alive (Akhtar, 1996, p. 65). Even paradise is described in the Holy Qur'ān (9:72; $32: 19 ; 35: 33)$ as a garden (or gardens). Also, the Holy Qur'ān $(6: 99,32: 27)$ mentions Allah's grace in providing the means to plant trees and cultivate crops, and the benefits derived from doing so. This tells a lot about the importance Islam attaches to the general development of plant species. While under the dominant conventional model of trading permits, a firm purchases the right to pollute the environment, under the Islamic system, a firm or an individual may end up purchasing his way into paradise in the hereafter by contributing to the building of forests through awqāf. By establishing a viable waqf in forestry and related activities, an individual or organization gets uninterrupted rewards in both this world and the next. 
The spiritual nature of waqf differentiates it from such conventional concepts like corporate social responsibility (CSR) and conventional community services. The central feature of waqf is its link with the rewards one expects to get in the hereafter. This motivates wealthy Muslims to invest their wealth in return for continued rewards even after they have long died. In Islamic environmental law, writes Arafa (2014), "all creatures in the universe perform two specific roles: a religious role that evidences God's perfection and presence, and a social role that serves man and other creatures" (pp. 468-469).

Waqf, in the modern period, contributes to reducing the need for government expenditure, and hence, releasing government money for other purposes (Çizakça, 1998, pp. 61-68). The history of waqf shows that it was used to provide both public and private goods. This, in the modern afforestation system, will mean that private charities will take care of planting trees while governments take care of other things. Here, waqf helps solve the problem of market failure where profit seeking entrepreneurs fail to invest because of fear of losses; nonprofit seeking individuals looking at the reward they will get in the next world fill their place. Thus, the complexity that exists with provision of public goods is solved by employing waqf (Çizakça, 1998, pp. 44-47). As a result, waqf helps the Islamic world develop a distinct solution to a wide class of problems regarding public goods (Kuran, 2001, pp. 849-852). For example, Akhtar (1996, p. 72) suggested that the institution of waqf should be reactivated in modern time and its land resources could be used for afforestation, watershed management, and wild-life conservation. He argued that evidence suggests that the waqf institution still exists in modern times with substantial amount of land resources in many Muslim countries.

The establishment of self-sustaining forest plantations and tree planting campaigns through waqf, that will later take care of itself as a semi-business venture, is a good proposal towards solving the problem of desertification that is threatening most of the Islamic world. How to establish an afforestation waqf? First of all, the wāqif (dedicator) will usually specify that the waqf fund is to be used for the development of forestry and tree planting. Thereafter, the administrators must abide by the directive from the wāqif. This is why, in the modern era, governments must create awareness among the wealthy for the need to establish afforestation awqāf. The administrators of afforestation $a w q \bar{a} f$ shall include those with expertise on agricultural economics, forestry, and environmental economics. Other than this, the general rules of establishing awq $\bar{a} f$ also apply here.

The Islamic capital market also has a special role to play in the modern development of waqf. Awqā certificates could be issued to raise cash $a w q \bar{a} f$, where individuals or institutions buy them in order to finance development projects (Hassan, 2010, p. 268). Already, sukūk have been used to finance waqf operations and development in Saudi Arabia, and Singapore (Ahmed, et al, 2015, p.27). Malaysia has also (in the middle of 2017) issued its first waqf shares through initial public offering (IPO). Where, Waqaf An-Nur Corp., a company set up by Johor Corp., a government-linked entity seeking to improve economic and societal development in the state, offered shares worth around $\$ 20 \mathrm{mn}$ backed by endowed land to retail and institutional investors and intends to use the proceeds to upgrade regional transport infrastructure in the state's capital of Johor Bahru (Maierbrugger, 2017).

\subsection{Islamic Finance as Panacea}

One of the major obstacles to afforestation activities in most OIC countries is the non-availability of finance. In rich countries, where the economic system is matured, the presence of developed financial systems has helped in accelerating afforestation activities. However, this is not the case in most OIC member countries where the financial system is underdeveloped. As a result, credit is not easy to get and most people think of only how to get the necessities of life. This calls for radical approaches to solve the problems. Islamic economics and finance has the potential to provide finance for the establishment of forestry resources. Islamic economics offer direct linkages between money, finance, and the real economy, thereby, logically removing the presence of interest rates from the resource allocation mechanism (Choudhury, 2010, p. 221). This means the removal of speculative use of money and investing of it where it matters: the real economy. Exorbitant interest rates and requirement of collateral are some of the factors that are barring poor farmers from accessing conventional loans. Today, Islamic finance has come of age. 
In Islamic finance, there are various alternative methods of raising finance in a Sharī ah-compliant manner. There are public and private sector sources of raising finances in an Islamic economy. Islamic financing tools such as mudārabah, mushārakah, and ijärah can be utilized for the purpose of financing afforestation. There is also microfinancing that can cater for the need of poor peasants. There is also the IDB that can provide long-term Islamic financing.

Many Islamic economists have decried the gradual disconnection of modern Islamic financial institutions from the real sector of the economy. Instead, these institutions are focused on mimicking conventional financial instruments. This is a far cry from the fundamental principles of Islamic economics that call for the abolition of interest and its replacement with profit and loss sharing. Under Islamic resources mobilization theory, money is put into uses in the real economy through participatory means and instruments in Sharíah-compliant spending outlets (Choudhury, 2007, p. 83). Today, Islamic financial institutions are mostly concerned with financing consumption instead of production envisaged by the early pioneers in the field. Choudhury $(2007$, p. 87) accused Islamic banks and financers of imitating and legitimizing the use of conventional present-valuation of cash flows method, and from there, the concept of time value of money. He argued that time valuation of money is simply the shadow price of interest rate. According to Pratiwi (2016, pp. 98-101), as well as Ahmed, Mohieldin, Verbeek, and Aboulmagd (2015, pp. 24-25), the commitment of Islamic banks and capital markets in addressing environmental and social issues is either small or non-existent. They blamed this scenario on the fact that "the contemporary notions of social and environmental sustainability have not been incorporated in maqassid and concepts related to Shari' ah compliance" (Ahmed et al., 2015 , p. 25). Their recommendations are that "an authoritative Shari'ah body, for example the OICaffiliated Islamic Fiqh Academy, would have to recognize environmental, social and cultural issues as important elements of maqāṣid al-Sharī ah to have the industry recognize these issues as integral to Islamic banking operations" (Ahmed et al., 2015, p. 25).

The role of $s u k \bar{u} k$ and cash waqf in financing tree planting activities is another area that policy makers should give the required attention it deserves. An example of socially responsible sukūk issued in recent years is the US\$ 500 million sukük issued in 2014 by the International Financial Facility for Immunization (IFFIm) to raise money for a vaccine fund (Ahmed et al., 2015, p. 26). Sukūk like green sukūk should be developed to serve afforestation purposes and ward off the threat of desertification in OIC countries. Recently, there have been some nonsignificant developments in Islamic-responsible investment funds (Ahmed et al., 2015, pp. 26-27). The Dow Jones (DJ) Islamic Market Sustainability Index, initiated in 2006, includes companies that meet the negative screening criteria resulting from Sharīah prohibitions as well as the positive screening criteria related to social and environmental issues (Ahmed, et al, 2015, p. 26). Thus, Sharīah funds should be mandated to include environment sustainability as one of their screening criteria.

The IDB has an important role to play in the provision of finance for afforestation activities. Just like it provides finance for the establishment of infrastructures and private sector loans, it should as well spearhead the move towards the provision of finance for the forestry sector. Thus, loans of this nature should fall under the category of policy lending instead of the more profit-oriented investment lending. Development institutions such as the World Bank have shifted their priorities away from investment lending towards policy lending (Abdullahi, 2006, p. 2; Kanbur, 1990, pp. 397-399). Giving policy advice is something that development agencies including the IDB are known for. The IDB should accelerate loans for the establishment of forestry resources together with expert advice on how to appropriately use the money for that particular purpose.

\subsection{Role of the Islamic Firm}

Recently, firms around the world have started to externally report their environmental and social performance together with their financial performance (Serafeim, 2014, p. 2). Neoclassical economists, particularly Milton Friedman (1970), has advanced the argument that pursuing any interest other than that of the shareholders will destroy the firm and distract it away from its major goal of making money for them. This has been the main position of firms in the US and the UK (Abdullahi, 2019b). 
However, recently things have started to change as firms are now taking other factors into consideration. But, the fact that today corporations are starting to pay attention to issues of sustainability is another matter from the actual motivation behind that. Most of them are paying attention to the environment because of pressures from the government, NGOs, and customers. This will, therefore, raise questions about the nature and quality of the environmental work they are executing. There are evidences that some of the corporate social responsibilities modern corporations are engaged in are just for public relation (PR) purposes, and not with the intention to actually contribute to environmental development. Thus, motivation is very important here as it helps explain the type and quality of the environmental work being undertaking. In a scenario where firms are forced to adopt environmental sustainability, they have to be monitored to ensure they do what they promised. Thus, there is a cost of monitoring that needs to be taken into consideration. However, where firms on their own want to adopt sustainability for reasons different from the above, such as gaining rewards in the hereafter, there is no need for monitoring. Therefore, this eliminates the cost of monitoring. This last scenario explains the position of an Islamic firm in an Islamic economy.

The Islamic firm has an important role to play in stopping desertification and deforestation. The underlying principles and foundations based on which a firm can be termed as an Islamic firm, include giving due recognition and respect to things created by Allah - from human beings, to animals, plants, and the physical environment. Choudhury (2010) has convincingly argued this case on the unity of knowledge in the Islamic system, "the Divine Law stands for unity of knowledge (Ilm) that is manifested by the high morality of justice ('Adl), balance (Mizan), human solidarity (Ikhwa), moderation (la-Israf), toleration, cooperation and consciousness (Tadabbur and Tafakkur) at all levels of inquiry" (pp. 209-210).

Thus, the Islamic firm shall not engage in overproduction and wastage of resources which have contributed to the deterioration of the environment. Hence, sponsoring the planting of trees shall be part of the responsibility of an Islamic firm towards Allah and the ummah. The Islamic firm can as well invest in agroforestry both for the sake of making money and the environment. This also means that, apart from possible environmental taxes paid by Islamic firms, another channel of contribution to forestry development by an Islamic firm is through corporate social responsibility where an Islamic firm sets aside funds for afforestation activities in their host communities. Apart from its responsibility to shareholders, employees, paying of $z a k \bar{a} h$, etc., an Islamic firm also has the responsibility to take care of the environment in which it is working (Abdullahi, 2019a; Abdullahi, 2019b).

Despite the established fact that Islam championed corporate social responsibilities (CSR) long before they became prominent in the conventional literature, modern Islamic firms are doing little to continue with that long tradition. The majority of firms operating in OIC countries that bear the name 'Islamic firm', for example, operate in the banking and finance industry. Other Islamic firms can be found in halāl cosmetics, and the foods and beverages industries. However, that notwithstanding, a lot of these firms do not have comprehensive corporate responsibility frameworks to attend to environmental matters (Farook \& Lanis, 2007, p. 218; Mallin, Farag, \& Ow-Yong, 2014, pp. 21-23; Ahmed et al., 2015, pp. 14-15; Pratiwi, 2016, pp. 98-101). This is a departure from the core philosophical underpinnings of the Islamic economic system.

The hope is that Islamic firms would differ from conventional firms which have become known for their environmentally harmful activities. Here, the Shari' ah boards of these firms have an important role to play in driving these changes. Sharī'ah boards (as bodies that constitute Islamic scholars), should be well aware of the Islamic teachings of unity (tawhì $\bar{l} \bar{\imath}$ concept) which encompasses unity between body and mind, man and his environment, unity of the ummah in following Allah's guidance, as well as the universal unity of all of Allah's creations in following His divine laws. It is, therefore, their responsibility to ensure that the company they are responsible for does not go against the unicity inherent in the tawhìd $\bar{\imath}$ concept. Embodied in this concept of unity is harmony between man and his environment as well as between the Islamic firm and its host environment. 
Recent developments in some OIC countries are giving signs of positive things to come from this sector. In Malaysia, the Securities Commission (SC) is launching a sustainable and responsible investment
(SRI) framework for investment funds for the Islamic finance industry. The initiative enables fund managers to offer products that combine SRI elements with Sharî ah-compliance at the same time.

\section{Figure (3) Harmony between the Islamic Firm and the Environment}

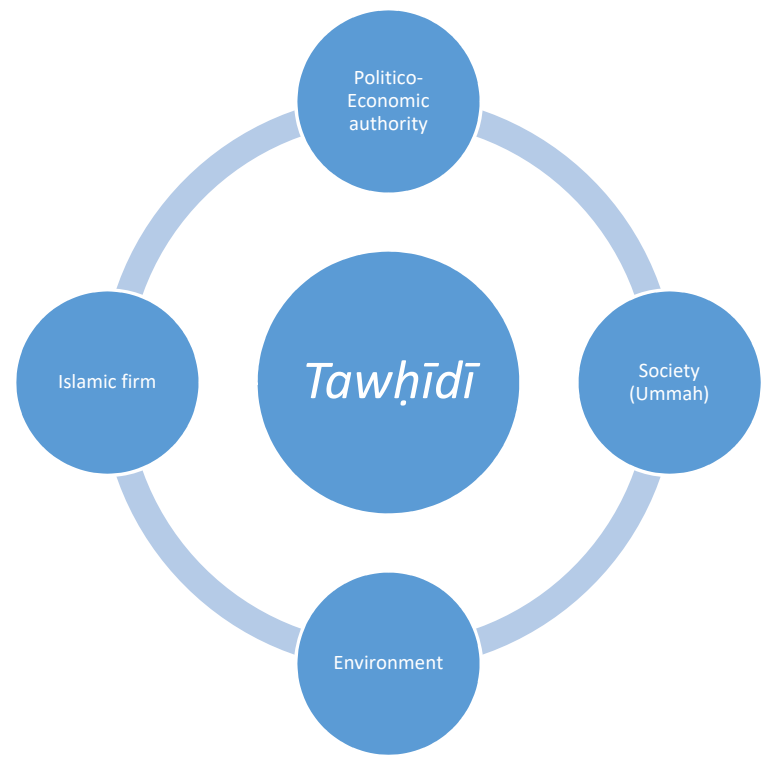

Source: Author's analysis.

\section{Conclusions}

This paper looks at the problem of deforestation and desertification in OIC member countries. It reviewed the problems and various efforts made to tackle them. It looks at the possible role Islamic economics and finance can play in resolving the crisis. Specifically, the paper highlights the role of Islamic economics in ensuring environmental sustainability through the instrumentality of zero interest Islamic financing tools such as sukūk, and mudārabah. It also highlights the role of the waqf institution, the participation of the Islamic state through the instrumentality of maquassid al-Sharī ah principles, and the active participation of the Islamic firm. The role of the tawhid $\bar{\imath}$ concept is central in these proposals as it is in all Islamic economic programs.

Now that disturbances and war are everywhere, the fate of the environment has become more fragile. Among the victims of these senseless wars are human beings, animals, plants, historical artifacts, records, billions of dollars' worth of infrastructures, and human civilization itself. At a time when man is planning to establish a habitat in space, his ancestral home, the Earth, has continued to bear the brunt of destruction brought about by man. Global warming is very real as witnessed through various indictors such as increase in global temperatures, rise in the sea level, and torrential rainfall. It is only dialogue, harmony, and fear of Allah that will ensure environmental sustainability. This is indeed the message of Islamic economics: justice, harmony, moderation, cooperation, assistance, selflessness, and cleanliness.

The long-term benefits of afforestation to the economy of OIC member countries is very huge. Chief among these, is the amount of land that will be reclaimed from the desert and put into productive use, which in turn, will have immediate effects on the nations' economy and the entire climate of the region and the wider world. The IDB as well as the OIC should recognize and impose environmental agendas on its member countries and trading partners. This is the only way for others to recognize and adopt them. 
OIC countries should also look at the possibility of establishing dedicated banks for financing afforestation and rolling back desertification. This will go a long way towards providing the sector with the necessary finance that it needs. These proposals are neither too much nor outrageous looking at the scale of the problem at hand. The afforestation bank, if created, will help in the provision of different kinds of technical, managerial, and consultancy services that include project identification, appraisal, and market surveys to determine the feasibility and viability of the proposed projects. Central banks in OIC countries should encourage commercial banks under their control to provide agroforestry business loans.

\section{References}

Abdullahi, S.I. (2006). The Bank programs in poor countries: matters arising (World Bank SUP). Retrieved from: https://bit.ly/2YsPlEb

Abdullahi, S.I. (2019a). Zakah as tool for social cause marketing and corporate charity: a conceptual study. Journal of Islamic Marketing, 10(1), 191-207.

Abdullahi, S.I. (2019b). Risk management and corporate governance: An Islamic perspective. In T. Azid, A. A. Alnodel, \& M. A. Qureshi (Eds.), Research in Corporate and Shariah Governance in the Muslim World: Theory and Practice (pp. 87-99). London, UK: Emerald publishing limited.

Ahmed, H., Mohieldin, M., Verbeek, J. and Aboulmagd, F. (2015). On the Sustainable Development Goals and the Role of Islamic Finance (World Bank Policy Research Working Paper No. WPS7266). Retrieved from: https://bit.ly/2Y9vrPu

Ahmed, K. (1997). The relevance of agroforestry to appropriate land management. Bayero Journal of social and management studies, 3\&4, 128-139.

Akhtar, M.R. (1996). Towards an Islamic approach for environmental balance. Islamic Economic Studies, 3(2), 57-76.

al-Anzi, E. and al-Duaij, N. (2004). Islamic Waqf and environmental protection. Codicillus, 45(2), 52-63.

Arafa, M.A. (2014). Islamic Policy of Environmental Conservation: 1,500 Years Old - Yet Thoroughly Modern. European Journal of Law Reform, 16(2), 465504.

Bashar, M.L.A. (1997). Price Control in an Islamic Economy. Journal of King Abdulaziz University: Islamic Economics, 9, 29-52.
Also, rich Muslim nations should invest in viable agroforestry businesses in other Muslims countries. Establishment of cooperative societies, specifically created for forestry related activities, should be encouraged. NGOs and other pressure groups should turn their radars towards afforestation activities and should forcefully fight against desertification and illegal loggings. Finally, governments should create awareness among the general public regarding their afforestation programs through social media, radio, television, and all other forms of media.

Briefing: Water scarcity - Liquidity crisis. (2016, November 5). The Economist. Retrieved from: https://econ.st/2Jp2hF1

Clark, C. (2017, February 9). This map shows the countries with the most 'toxic' environments on Earth. Business Insider. Retrieved from: https://bit.ly/2YCR6iw

Choudhury, M.A. (2007). Islamic Economics and Finance: Where Do They Stand? In M. Iqbal, S. S. Ali, \& D. Muljawan (Eds.), Advances in Islamic economics and finance, Volume 1: Proceedings of $6^{\text {th }}$ International Conference on Islamic Economics and Finance (pp. 75-98). Jeddah, KSA: Islamic Development Bank.

Choudhury, M.A. (2010). The Dynamics of the Shari'ah and the World-System. Journal of King Abdulaziz University: Islamic Economics, 23(2), 201-227.

Çizakça, M. (1998). Awqaf in history and its implications for modern Islamic economies. Islamic Economic Studies, 6(1), 43-70.

Courcelle, M., Sevaistre, P. and Stinzty, O. (2004). Sustainability Impact Assessment [SIA] of the EU-ACP Economic Partnership Agreements - Regional SIA: West African ACP countries. London, UK: PricewaterhouseCoopers. Retrieved from: https://bit.ly/2yi2IbQ

Dasgupta, P. and Maler, K.-G. (1991). The environment and emerging development issues. In S. Fischer, D. de Tray, \& S. Shah (Eds.), Proceedings of the World Bank annual conference on development economics 1990 (pp. 101-147). Washington, USA: The World Bank. Retrieved from: https://bit.ly/2YrrDs5 
Dasgupta, S., Hamilton, K., Pagiola, S. and Wheeler, D. (2008). Environmental Economics at the World Bank. Review of Environmental Economics and Policy, 2(1), 4-25.

Dinda, S. (2004). Environmental Kuznets Curve Hypothesis: A Survey. Ecological Economics, 49(4), 431-455.

Djanibekov, U. (2014). Trees, crops, and rural livelihoods: Afforestation of marginal croplands in Uzbekistan (Unpublished doctoral dissertation). University of Bonn, Bonn, Germany. Retrieved from: http://hss.ulb.uni-bonn.de/2014/3641/3641.pdf

Djanibekov, U., Khamzina, A., Villamor, G.B. and Lamers, J. P.A. (2013). Economic analysis of afforestation of marginal croplands in Uzbekistan (Center for International Development and Environmental Research Working Paper). Retrieved from: https://ageconsearch.umn.edu/record/159089/

Djanibekov, U. and Villamor, G.B. (2015). Spillover effects of market-based instruments under revenue uncertainty in Jambi Province, Indonesia. Paper presented at the 29th ICAE - International Conference of Agricultural Economists: Agriculture in an Interconnected World, Milan, Italy. Retrieved from: https://bit.ly/2MlTIdP

Emewu, I. (2017, July 6). China creates world's first forest city with $1 \mathrm{~m}$ plants. The Sun Nigeria. Retrieved from: https://bit.ly/2Gwlctp

Farook, S. and Lanis, R. (2007). Banking on Islam? Determinant of corporate social responsibility disclosure. In M. Iqbal, S. S. Ali, \& D. Muljawan (Eds.), Advances in Islamic economics and finance, Volume 1: Proceedings of $6^{\text {th }}$ International Conference on Islamic Economics and Finance (pp. 217-247). Jeddah, KSA: Islamic Development Bank.

For peat's sake: Despite tough talk, Indonesia's government is struggling to stem deforestation. (2016, November 26). The Economist. Retrieved from: https://econ.st/2Gwln83

Friedman, M. (1970). The social responsibility of business is to increase its profits. New York Times Magazine, 32(33), 122-126.

Maierbrugger, A. (2017, July 11). Malaysia is reviving widely untapped waqf segment of finance. Gulf Times. Retrieved from: https://bit.ly/2K6KYWk

Hasan, Z. (2006). Sustainable Development from an Islamic Perspective: Meaning, Implications, and Policy Concerns. Journal of King Abdulaziz University: Islamic Economics, 19(1), 3-18.
Hasan, Z. (2008). Markets and the role of government in an economy from Islamic perspective (MPRA Paper No. 12233). Retrieved from: https://bit.ly/2MlTfIB

Hassan, M. K. and Ashraf, A. (2010). An integrated poverty alleviation model combining Zakat, Awqaf and micro-finance. In A. G. Ismail, M. E. Mat Hassan, N. Ismail, \& S. Shahimi (Eds.), Proceedings of Seventh International Conference - The Tawhidi Epistemology: Zakat and Waqf Economy (pp. 261-281). Bangi, Malaysia: Institut Islam Hadhari, Universiti Kebangsaan Malaysia.

Hepburn, C. (2010). Environmental policy, government, and the market. Oxford Review of Economic Policy, 26(2), 117-136.

Hillman, A.L. (2003). Public Finance and Public Policy: Responsibilities and Limitations of Government. Cambridge, UK: Cambridge university press.

Ibrahim, K.M. and Muhammad, S.I. (2015). A review of afforestation efforts in Nigeria. International Journal of Advanced Research in Engineering and Applied Sciences, 4(12), 24-37.

Kadandani, B.I. (2005). The economic and environmental consequences of wood fuel market: A case study of Mariri in Kano. Bayero journal of social and management studies, 10, 27-59.

Kanbur, R. (1990). Projects versus policy reforms. In S. Fischer, D. de Tray, \& S. Shah (Eds.), Proceedings of the World Bank annual conference on development economics 1990 (pp. 397-413). Washington, USA: The World Bank. Retrieved from: https://bit.ly/2YrrDs5

Kuran, T. (2001). The Provision of Public Goods under Islamic Law: Origins, Impact, and limitations of the Waqf System. Law \& Society Review, 35(4), 841-898.

Lipsey, R.G. and Chrystal, K.A. (2004). Economics. New Delhi, India: Oxford University Press.

Mallin, C., Farag, H. and Ow-Yong, K. (2014). Corporate social responsibility and financial performance in Islamic banks. Journal of Economic Behavior \& Organization, 103(Supplement), 21-38.

al-Naisabouri, Muslim bin al-Hajjaj. (1991). Sahih Muslim. Beirut: Dar Ihya' al-Turath al-Arabi.

Oran, A. F. (2010). An Islamic Socio-Economic Public Interest Theory of Market Regulation. Review of Islamic Economics, 14(1), 125-146.

Pratiwi, A. (2016). Islamic banking contribution in sustainable socioeconomic development in Indonesia: An epistemological approach. Humanomics, 32(2), 98120. 
al-Raysuni, A. (1992). Nazriyyat al-Maqasid 'Inda alImam al-Shatibi [The Theory of Objectives of Imam al-Shatibi]. Riyadh, KSA: Dar al-Alamiyyah lil Kitab al-Islami.

Roger, W. (1984). Economic, Resources, and Policy. London, UK: Longman publishing.

Sargent, C. and Bass, S. (1992). The future shape of forests. In J. Holmberg (Ed.), Policies for a Small Planet: From the International Institute for Environment and Development (pp. 195-224). London, UK: Earthscan.

Serafeim, G. (2014). The Role of the Corporation in Society: An Alternative View and Opportunities for Future Research (Harvard Business School Working Paper No. 14-110). Retrieved from: https:/hbs.me/2YIrZaO

Shihata, I.F. (1992). The World Bank and the Environment: a Legal Perspective. Maryland Journal of International Law and Trade, 16(1), 1-42.
Special report: The great race - The invisible green hand. (2002, July 6). The Economist. Retrieved from: https://econ.st/2Kd6bOd

Stern, D.I. (2003). The Environmental Kuznets Curve (International Society for Ecological Economics Working Paper). Retrieved from: http://isecoeco.org/pdf/stern.pdf

Stern, D.I. (2004). The Rise and Fall of the Environmental Kuznets Curve. World Development, 32(8), 1419-1439.

Third World Institute. (1999). The World Guide 1999/2000: An Alternative Reference to the Countries of Our Planet. Montevideo, Uruguay: Author.

Yazdanpanah, H., Eitzinger, J. and Baldi, M. (2017). Analysis of the extreme heat events in Iran. International Journal of Climate Change Strategies and Management, 9(4), 418-432.

Shafiu Ibrahim Abdullahi works with Sule Lamido University, Kafin-Hausa, Jigawa state, Nigeria. He has previously worked in media and banking industries in Nigeria. He has published papers in international journals such as the International Journal of Ethics and Systems (Emerald), Journal of Islamic Marketing (Emerald), Middle East Journal of Management (Inderscience), International Journal of Islamic Marketing and Branding, (Inderscience), and Journal of Advanced Studies in Finance, among others. His works have also appeared in Newspapers and as book chapters. He has also reviewed for the Journal of Islamic Marketing, International Journal of Islamic Marketing and Branding, and International Journal of Islamic and Middle Eastern Finance and Management.

Email: shafiuibrahim@gmail.com 


\title{
تمويل استزراع الغابات في دول منظمة التعاون الإسلامي: ما دور الاقتصاد والتمويل الإسلامي؟
}

\author{
شفيع إبراهيم عبدالله \\ جامعة سول لاميدو ، كافين-هوسا ، ولاية جيغاوا ، نيجيريا
}

المستخلص: تتناول هذه الورقة الحفاظ على البيئة ضمن الفهم المتزايد للحاجة الملحة لمواجهة تهديد التصحر وإزالة الغابات من خلال مخططات التشجير في البلدان الأعضاء في منظمة المؤتمر الإسلامي. تعد إزالة الغابات واحدة من المساهمين الرئيسيين في انبعاثات الغازات الدفيئة العالمية وتدهور النظم

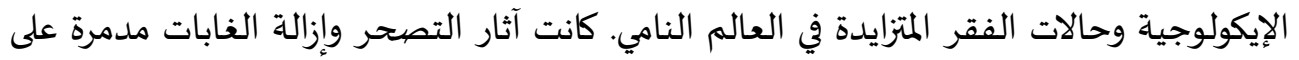

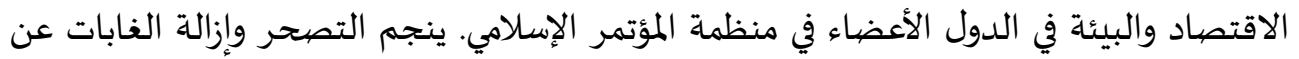
الأنشطة البشرية الخاطئة مثل والممارسات الزراعية الضارة ، وكذلك قطع الأشجار بطرق عشوائية لإفساح المجال أمام المباني والمزارع في المدن. تبين هذه الورقة أنه يمكن حل سوء التماء التعاملات السابقة

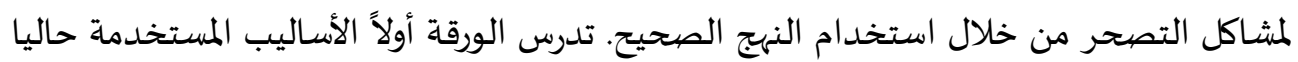

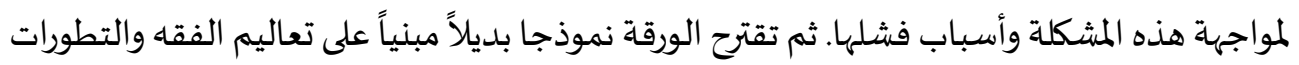
الحديثة في الاقتصاد والتمويل الإسلامي. تقوم الورقة ببيان الأساليب التقليدية والإسلامية لحل مشاكل التصحر وإزالة الغابات وارتفاع درجة الحرارة في دول منظمة التعاون الإسلامي. كما تحدد التهات

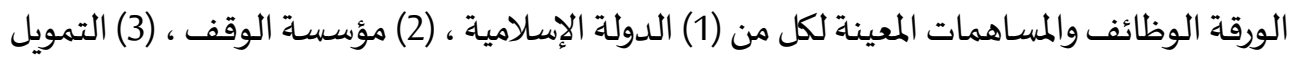
الإسلامي ، (4) الشركات الإسلامية. الكلمات الدَّالة: الاستزراع ، التصحر ، إزالة الغابات ، فشل السوق. تصنيف JEL تصنيف B1, E2, E3, H2, H3: KAUJIE 